\title{
PENERAPAN STRATEGI PEMBELAJARAN BERBASIS MASALAH UNTUK MENINGKATKAN HASIL BELAJAR SISWA
}

\author{
NUR ANISAH \\ SDN 03 Kutoharjo Kendal \\ Email : nuranisah250566@gmail.com
}

\begin{abstract}
ABSTRAK
Jenis penelitian ini merupakan Penelitian Tindakan Kelas (PTK) yang dilakukan di SDN 03 Kutoharjo Kaliwungu Kendal. Subjek dalam penelitian ini merupakan siswa kelas VI.A SDN 03Kutoharjo Kaliwungu Kendal sebanyak 1 kelas yaitu 23 siswa. Soal tes hasil belajar dalam bentuk pilihan ganda dengan 4 pilihan jawaban sebanyak 20 soal dan lembar format observasi digunakan sebagai Teknik pengumpulan data. Teknik analisis data yang digunakan adalah analisis data kualitatif dan kuantitatif dengan metode observasi. Hasil penelitian menujukkan bahwa sebelum diberikan tindakan, dari hasil pre tes diperoleh rata-rata pengetahuan awal siswa tentang materi perubahan sifat benda sebesar $0 \%$ atau tidak seorangpun siswa yang dinyatakan tuntas belajar. Setelah dilakukan siklus I dari hasil postes rata-rata hasil belajar siswa meningkat dengan jumlah siswa yang telah tuntas belajar sebanyak 15 siswa atau sebesar 65,2\%. Karena jumlah siswa yang tuntas hanya $65,2 \%$ atau kurang dari $85 \%$ maka secara klasikal siswa masih belum berhasil mencapai ketuntasan belajar secara klasikal sehingga masih perlu dilakukan perbaikan pada siklus II. Setelah dilakukan perbaikan pembelajaran pada siklus II dari hasil postes siklus II rata-rata hasil belajar siswa pada materi perubahan sifat benda meningkat menjadi 22 siswa atau 95,6\%. Karena jumlah siswa yang tuntas sebesar 95,6\% atau lebih dari 85\% maka secara klasikal siswa dinyatakan telah berhasil mencapai ketuntasan belajar sehingga dianggap cukup dan tidak perlu dilakukan siklus selanjutnya. Karena itu, berdasarkan hasil penelitian tindakan yang dilakukan selama 2 siklus dapat disimpulkan bahwa penggunaan strategi pembelajaran berbasis masalah dapat meningkatkan hasil belajar siswa pada mata pelajaran IPA materi pokok perubahan sifat benda di kelas VI.A SDN 03 Kutoharjo Kaliwungu Kendal.
\end{abstract}

Kata Kunci : Penelitian tindakan kelas, hasil belajar, pembelajaran berbasis masalah

\section{PENDAHULUAN}

Hasil belajar dan ketuntasan belajar yang diperoleh siswa merupakan dasar keberhasilan siswa dalam belajar termasuk belajar IPA. Kenyataannya, hasil belajar IPA yang siswa diperoleh masih sangat rendah. Rendahnya hasil belajar IPA siswa juga tampak di SDN 03 Kutoharjo Kaliwungu Kendal. Observasi awal penulis ditemukan bahwa rata-rata hasil belajar IPA siswa kelas VI.A pada semester genap tahun ajaran 2016/2017 sejumlah 23 siswa sebelum diberikan tindakan, dari hasil pre tes diperoleh rata-rata pengetahuan awal siswa tentang materi perubahan sifat benda sebesar 0\% atau tidak seorangpun siswa yang dinyatakan tuntas belajar.

Rendahnya hasil belajar siswa dikarenakan guru masih menggunakan metode ceramah danstrategi pembelajaran masih bersifat tradisional. Dalam mengajarkan IPA di depan kelas, materiyang diajarkan guru hanya berasal dari buku teks sehingga pengembangan materi berkurang dan guru juga kurang melibatkan keaktifan siswa dalam belajar. Akibatnya hasil yang dicapai siswa menjadi kurang optimal. Dari permasalahan tersebut, maka diperlukan sutau strategi pembelajaranyang tepat dengan melibatkan siswa secara aktif dalam belajar sehingga hasil belajar yang dicapai siswa menjadi lebih optimal. Salah satu strategi pembelajaran yang dapat digunakan guru dalam mengajarkan IPA adalah strategi pembelajaran berbasis masalah. Strategi ini secara teori lebih menekankan pada penggunaan masalah sebagai langkah awal dalam mengumpulkan dan mengintegrasikan pengetahuan baru siswa melalui kegiatan penyelidikan-penyelidikan untuk memecahkan masalah yang diberikan oleh guru. Dengan demikian, penggunaan strategi pembelajaran berbasis masalah diharapkan mampu meningkatkan hasil belajar siswa pada mata pelajaran sekolah khususnya mata pelajaran IPA pada siswa kelas VI.A SDN 03 Kutoharjo Kaliwungu Kendal. 
Belajar ialah suatu proses usaha yang dilakukan seseorang untuk memperoleh suatu perubahan tingkah laku yang baru secara keseluruhan, sebagai hasil pengalamannya sendiri dalam interaksi dengan lingkungannya (Slameto, 2010:2). Secara umum belajar dapat dipahami sebagai tahapan perubahan tingkah laku individu yang relatif menetap sebagai hasil pengalaman dan interaksi dengan lingkungan yang melibatkan proses kognitif (Syah, 2010:68). Belajar adalah sebagai suatuproses dimana suatu organisma berubah perilakunya sebagai akibat dari pengalaman (Gagne dalamSagala, 2009:13). Berdasarkan beberapa pendapat di atas, dapat disimpulkan bahwa belajar adalahperubahan tingkah laku baik yang diperoleh dari latihan, pengalaman dan berinteraksi dengan lingkungan sehingga belajar tidak hanya mengingat, tetapi lebih kepada mengalami.

Hasil-hasil belajar adalah pola-pola perbuatan, nilai-nilai, pengertian-pengertian, sikapsikap, apresiasi, abilitas dan keterampilan (Hamalik, 2010:31). Hasil kegiatan belajar mengajar tercermindalam perubahan perilaku, baik secara material substansial, struktural-fungsional, maupun secarabehaviour (tingkah laku) (Djamarah dan Zain, 2010:11). Hasil belajar adalah kemampuan- kemampuan yang dimiliki siswa setelah ia menerima pengalaman belajarnya. (Sudjana, 2009:22). Berdasarkan pendapat-pendapat di atas, dapat disimpulkan bahwa perubahan tingkah laku yang dialami siswa baik dalam bentuk pengetahuan, keterampilan, sikap, maupun nilai-nilai yang diperoleh siswa yang merupakan puncak dari proses pembelajaran yang dialaminya berkat pengalaman dan interaksinya terhadap kegiatan pembelajaran yang dilakukan di dalam kelas disebut sebagai hasil belajar.

Masalah dapat mendorong keseriusan, inquiry, dan berpikir dengan cara yang bermakna dan sangat kuat/powerfull (Rusman, 2010:230). Strategi pembelajaran berbasis masalah merupakan inovasi dalam pembelajaran karena dalam proses belajar mengajar, kemampuan berpikir siswa betul-betul dioptimalisasikan melalui proses kerja kelompok atau tim yang sistematis, sehingga siswa dapat memberdayakan, mengasah, menguji, dan mengembangkan kemampuan berpikirnya secara berkesinambungan (Tan dalam Rusman, 2010:229). Pembelajaranberbasis masalah adalah suatu pendekatan untuk membelajarkan siswa untuk mengembangkan keterampilan berpikir dan keterampilan memecahkan masalah, belajar peranan orang dewasa yangotentik serta menjadi pelajar mandiri (Jauhar, 2011:88). Berdasarkan pengertian-pengertian di atas, dapat disimpulkan bahwa strategi pembelajaran berbasis masalah adalah strategi pembelajaran yang merangsang keaktifan siswa dengan mengoptimalkan daya pikir siswa secara berkesinambungan dengan metode kerja kelompok/ tim sehingga siswa mampu memecahkan masalah yang dihadapi terutama masalah belajar.

Untuk mengoptimalkan kualitas proses dan hasil pembelajaran berbasis masalah, kondisi-kondisi yang sesuai dengan karakteristik peserta didik untuk belajar efektif, yaitu: (Konwles dalam Riyanto, 2010:286) Suatu lingkungan pelajaran yang ditandai oleh kenyamanan fisik; kepercayaan timbal balik dan rasa hormat, bantuan timbal balik yang bermanfaat; kebebasan untuk mengungkapkan, diterimanya perbedaan, pengalaman sebagai tujuan belajaritu sendiri; belajar menerima tanggung jawab untuk perencanaan dan operasi belajar; peserta didik mempunyai suatu komitmen untuk mengambil bagian dalam proses pembelajaran dengan aktif, dan merasakan kemajuan ke arah tujuan mereka sendiri. 2010:293)

Tahapan prosedur pembelajaran berbasis masalah, yakni: (Arends dalam Riyanto,

Tahap-1: Orientasi siswa pada masalah. Guru menjelaskan tujuan pembelajaran, menjelaskan logistic yang dibutuhkan, mengajukan fenomena atau demonstrasi atau cerita untuk memunculkan masalah, memotivasi siswa terlibat dalam pemecahan masalah yang dipilih.

Tahap-2: Mengorganisasikan siswa untuk belajar. Guru membantu siswa untuk mendefinisikan dan mengorganisasikan tugas belajar yang berhubungan dengan masalah tersebut.

Tahap-3: Membimbing penyelidikan individual maupun kelompok. Guru mendorong siswa untuk mengumpulkan informasi yang sesuai, melaksanakan eksperimen, untuk 
mendapatkan penjelasan dan pemecahan masalah.

Tahap-4: Mengembangkan dan menyajikan hasil karya. Guru membantu siswa dalam merencanakan dan menyiapkan karya yang sesuai seperti laporan, video, dan model serta membantu mereka untuk berbagi tugas dengan temannya.

Tahap-5: Menganalisis dan mengevaluasi proses pemecahan masalah. Guru membantu siswa untuk melakukan refleksi atau evaluasi terhadap penyelidikan merekadan prosesproses yang mereka gunakan.

\section{METODE PENELITIAN}

Penelitian ini merupakan jenis penelitian tindakan kelas (PTK) dengan ciri, adanya siklus-siklus yang berfungsi sebagai pemecah menuju praktek pembelajaran yang lebih baik. Penelitian ini dilakukan di SDN 03 Kutoharjo Kaliwungu Kendal. Waktu penelitian dilakukan pada tahun pelajaran 2016/2017, selama 3 bulan mulai bulan Agustus hingga Oktober 2016. Subjek dalam penelitian ini adalah siswa kelas VI.A SDN 03 Kutoharjo Kaliwungu Kendal tahun pelajaran 2016/2017 sebanyak 23 siswa. Desain pelaksanaan PTK pada penelitian ini mengacu pada modelPTK Hopkins yang diadopsi dari Sanjaya (2010:54) .

Menurut langkah-langkah penelitian tindakan kelas (PTK), secara umum prosedur pembelajaran dilakukan sebanyak 2 siklus dengan tiap siklusnya terdiri atas 4 tahapan (perencanaan, pelaksanaan, observasi serta refleksi). Pada tes hasil belajar dan format lembar observasi digunakan sebagai teknik pengumpulan data penelitian yang dilakukan. Tes hasil belajaruntuk mengetahui hasil belajar sains pada aspek kognitif sejumlah 20 soal pada materi perubahansifat benda dalam bentuk pilihan berganda. Tes pilihan berganda dipilih karena tes dianggap tes yang baik dan paling banyak digunakan dalam tes standar. Sedangkan lembar observasi digunakanuntuk mengetahui kesesuaian tindakan dengan rencana yang telah disusun disediakan lembar observasi. Lembar observasi terdiri atas lembar observasi keaktifan siswa selama pembelajaran berlangsung dan lembar observasi kegiatan guru selama proses pembelajaran dengan menggunakan strategi pembelajaran berbasis masalah.

\section{HASIL DAN PEMBAHASAN}

\section{Hasil Penelitian}

Sebelum diberikan pertemuan pembelajaran, siswa diberikan soal pre tes untuk mengetahui pengetahuan awal siswa tentang materi pokok perubahan sifat benda. Soal pre tes yang diberikan sejumlah 20 soal dalam bentuk pilihan ganda. Hasil pretes menunjukan bahwa total 23 siswa yang diberikan pre tes dinyatakan tidak tuntas atau dengan kata lain seluruh siswa mendapatkan nilai dibawah 70 (nilai KKM mata pelajaran IPA di SDN 03 KutoharjoKaliwungu Kendal yaitu 70).

Tabel 2. Hasil pembelajaran siswa pada pretest

\begin{tabular}{lllll}
\hline No & Skor nilai & Frekuensi & $\%$ & Keterangan \\
\hline 1 & $0-30$ & 0 & $0 \%$ & Rendah \\
2 & $31-60$ & 23 & $100 \%$ & Sedang \\
3 & $61-90$ & 0 & $0 \%$ & Tinggi \\
& JUMLAH & 23 siswa & $100 \%$ & \\
\hline
\end{tabular}

Berdasarkan hasil tersebut dapat disimpulkan bahwa pengetahuan awal siswa kelas VI.A SDN 03 Kutoharjo Kaliwungu pada materi perubahan sifat benda masih sangat rendah, hal tersebut berkaitan dengan tingkat ketuntasan siswa masih $0 \%$ sehingga perlu dilakukan tindakan pada siklus I dengan menggunakan strategi pembelajaran berbasis masalah. 


\section{Siklus I}

Pelaksanaan penelitian tindakan kelas yang dilakukan peneliti bersama dengan kolaborator dilakukan melalui tes pada pertemuan terakhir (ke-3) tiap siklus. Setelah pertemuan terakhir dilakukan refleksi untuk mengetahui adanya peningkatan atau tidak pada penelitian ini. Pada post tes siklus I hasil pembelajaran siswa dengan menggunakan strategi pembelajaran berbasis masalah, tingkat ketuntasan menunjukan peningkatan pada skor nilai siswa namun masih ada beberapa siswa yang belum tuntas, maka dari itu perlu dilakukan perbaikan pada siklus berikutnya.

Tabel 3. Hasil pembelajaran siswa pada post tes siklus I

\begin{tabular}{lllll}
\hline No & Skor nilai & Frekuensi & $\%$ & Keterangan \\
\hline 1 & $0-30$ & 0 & $0 \%$ & Rendah \\
2 & $31-60$ & 7 & $30,4 \%$ & Sedang \\
3 & $61-90$ & 16 & $69,6 \%$ & Tinggi \\
& JUMLAH & 23 siswa & $100 \%$ & \\
\hline
\end{tabular}

Berdasarkan tabel di atas menunjukkan bahwa penggunaan strategi pembelajaran berbasis masalah pada mata pelajaran IPA terkait perubahan sifat benda di SDN 03 Kutoharjo Kaliwungu siklus I menunjukan peningkatan namun belum optimal. Dari total 23 siswa hanya 15 siswa yang memperoleh nilai tuntas dengan tingkat prosentase $65,2 \%$.

\section{Siklus II}

Pelaksanaan penelitian tindakan kelas yang dilakukan peneliti bersama dengan kolaborator dilakukan melalui tes pada pertemuan terakhir (ke-3) tiap siklus. Setelah post tes siklus I selanjutnya dilakukan post tes pada siklus II, hal ini dikarenakan hasil post tes pada siklusI belum optimal. Pada post tes siklus II hasil pembelajaran siswa dengan menggunakan strategi pembelajaran berbasis masalah, tingkat ketuntasan menunjukan peningkatan yang signifikan pada skor nilai siswa, berdasarkan hal tersebut tidak perlu dilakukan perbaikan pada siklus berikutnya.

Tabel 4. Hasil pembelajaran siswa pada post tes siklus II

\begin{tabular}{lllll}
\hline No & Skor nilai & Frekuensi & $\%$ & Keterangan \\
\hline 1 & $0-30$ & 0 & $0 \%$ & Rendah \\
2 & $31-60$ & 1 & $4,3 \%$ & Sedang \\
3 & $61-90$ & 22 & $95,6 \%$ & Tinggi \\
& JUMLAH & 23 siswa & $100 \%$ &
\end{tabular}

Berdasarkan tabel di atas menunjukkan bahwa penggunaan strategi pembelajaran berbasis masalah pada mata pelajaran IPA terkait perubahan sifat benda di SDN 03 Kutoharjo Kaliwungu siklus I menunjukan peningkatan yang optimal. Dari total 23 siswa, 22 siswa memperoleh nilai tuntas dengan tingkat prosentase 95,6\%.

2. Pembahasan Penelitian

Berdasarkan hasil penelitian tindakan kelas yang telah dilakukan selama dua siklus terbukti bahwa penggunaan strategi pembelajaran berbasis masalah menunjukkan adanya peningkatan hasil belajar mata pelajaran IPA siswa kelas VI.A SDN 03 Kutoharjo Kaliwungu. Sebelum diberikan tindakan dari hasil pretes diperoleh rata-rata pengetahuan awal siswa tentang materi perubahan sifat benda sebesar 49,5. Setelah dilakukan siklus I dari hasil postes rata-rata hasil belajar siswa meningkat menjadi sebesar 69,3. Selanjutnya setelah dilakukan perbaikan pembelajaran pada siklus II dari hasil postes siklus II rata-rata hasil belajar siswa pada 
materi perubahan sifat benda meningkat menjadi sebesar 77,6. Peningkatan hasil belajar siswa juga tampak dari persentase ketuntasan belajar siswa secara klasikal. Sebelum diberikan tindakan dari hasil pretes tidak seorang pun siswa yang mencapai ketuntasan belajar $(0 \%)$. Setelah dilakukan siklus I, persentase ketuntasan belajar siswa secara klasikal meningkat menjadi sebesar $65,2 \%$. Selanjutnya setelah perbaikan pembelajaran pada siklus II dilakukan persentase ketuntasan belajar siswa secara klasikal juga mengalami peningkatan menjadi sebesar $95,6 \%$.

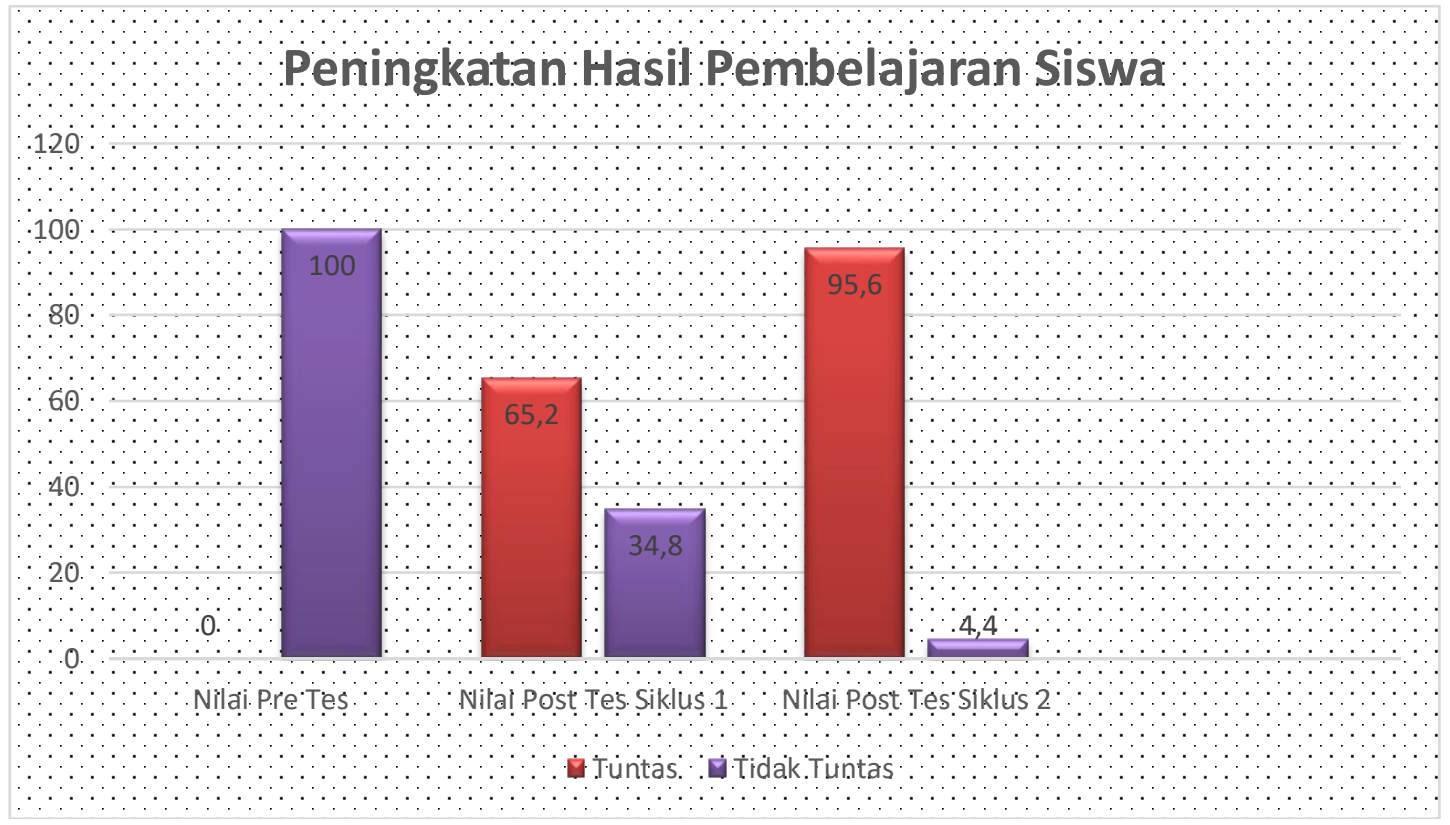

Gambar 1. Grafik Peningkatan Hasil Pembelajaran Siswa

\section{Penelitian yang Relevan}

Sukarni (2011) meneliti tentang model pembelajaran Problem Based Learning dan Expositori menyimpulkan pada siklus I terdapat 53\% siswa yang tuntas dan siklus II menjadi 100\%. Demikian halnya dengan penelitian Nurhidayah (2012) menunjukan bahwa penerapan pembelajaran model Problem Based Learning dapat meningkatkan hasil belajar mata pelajaran PKn, yang ditandai skor rerata aktivitas siswa relevan dengan pembelajaran mengalami peningkatan dari siklus pertama $(70,33)$ sampai siklus ke dua $(85,55 \%)$ mengalami kenaikan sebesar 15,22\%. Purwanto (2014) meneliti tentang implementasi pembelajaran Problem Based Learning menunjukkan hasil belajar siswa meningkatkan siklus I (80\%), dan siklus II (96,7\%). Penelitian Trubus Triyantono (2016) meningkatnya aktifitas siswa pada pembelajaran PKn pada setiap siklusnya. Perolehan nilai rata-rata kelas 65 pada kondisi awal dengan ketuntasan belajar 37,50\%, pada siklus I meningkat dengan rata-rata menjadi 70,63 dengan ketuntasan belajar 68,75. Pada siklus II meningkat lagi dengan rata-rata kelas 83,13 dengan ketuntasan belajar sebesar 93, 75\%. (Wisanggeni :2016).

Berdasarkan yang relevan dari hasil-hasil penelitian terdahulu dapat disimpulkan bahwa penelitian tindakan kelas dengan menggunakan model pembelajaran Probelm Based Learning sudah pernah dilakukan oleh peneliti lain. Perbedaannya dengan penelitian ini terletak pada subjek, kajian teori, materi, dan instrumen penelitiannya.

Keberhasilan tindakan strategi pembelajaran berbasis masalah tampak selama proses pembelajaran. Hasil observasi peneliti bersama kolaborator pada siklus I, keaktifan siswa dalam bertanya maupun mengungkapkan pendapat serta kerjasama dalam menyelesaikan tugas kelompok yang diberikan guru masih tergolong kurang. Hal ini dikarenakan selama tindakan siklus I, guru kurang dalam mengarahkan siswa untuk memecahkan masalah, kemudian guru kurang dalam membimbing siswa guna mengembangkan dan menyajikan hasil penyelesaian masalah serta guru kurang dalam merangsang pemahaman siswa melalui pertanyaan- 
pertanyaan. Berdasarkan hasil tersebut maka perlu dilakukan perbaikan pembelajaran pada siklus II. Selanjutnya setelah dilakukan perbaikan pembelajaran pada siklus II, tampak bahwa keaktifan siswa dalam bertanya maupun mengungkapkan pendapat serta kerjasama dalam menyelesaikan tugas kelompok yang diberikan guru masih tergolong mengalami peningkatan. Hal ini dikarenkan selama tindakan siklus II, kegiatan guru dalam mengarahkan siswa pada masalah kemudian memecahkan masalah, membimbing siswa mengembangkan dan menyajikan hasil penyelesaian masalah serta merespon pertanyaan atau pendapat dilakukan guru dengan komunikasi yang sangat baik. Dengan demikian, berdasarkan hasil temuan penelitian yang telah dilakukan selama 2 siklus dapat disimpulkan bahwa penggunaan strategi pembelajaran berbasis masalah dapat meningkatkan hasil belajar siswa pada mata pelajaran IPA materi pokok perubahan sifat benda di kelas VI.A SDN 03 Kutoharjo Kaliwungu.

\section{KESIMPULAN DAN SARAN}

Peningkatan hasil belajar sains siswa dapat dilihat dari rata-rata nilai maupun ketuntasan belajar siswa secara klasikal; (1) Hasil pretes diperoleh rata-rata pengetahuan awal siswa sebesar 49,5 dan tidak seorang siswapun atau $0 \%$ siswa yang dinyatakan tuntas belajar, kemudian setelah dilakukan siklus I, rata-rata hasil belajar siswa meningkat menjadi sebesar 69,3 dengan jumlah siswa yang telah tuntas belajar sebanyak 15 siswa atau sebesar 65,2\%, kemudian dilakukan perbaikan pada siklus II, rata-rata hasil belajar siswa pada materi perubahan sifat benda meningkat menjadi sebesar 77,6 dengan jumlah siswa yang tuntas dalam belajar sebanyak 22 siswa atau 95,6\%. Berdasarkan hasil tersebut dapat disimpulkan bahwa penggunaan strategi pembelajaran berbasis masalah dapat meningkatkan hasil belajar siswa pada mata pelajaran IPA materi pokok perubahan sifat benda khususnya di kelas VI.B SDN 03 Kutoharjo Kaliwungu.

Peneliti menyarankan agar (1) Kepada guru kelas menggunakan strategi pembelajaran berbasis masalah secara terus menerus atau berkelanjutan agar siswa lebih terbiasa, terlatihdan terampil dalam menyelesaikan masalah yang dihadapkan kepada mereka sehingga diharapkan dapat meningkatkan hasil belajar siswa menjadi lebih baik, (2) Kepada kepalasekolah agar lebih memperhatikan efisiensi dan efektivitas proses pembelajaran yang dilakukan guru di dalam kelas, salah satunya dengan memberikan motivasi kepada para guru untuk dapat menyusun dan merancang strategi pembelajaran yang interaktif dan edukatif yang melibatkan keaktifan siswa sehingga dapat hasil belajar menjadi lebih baik,

Berdasarkan penelitian ini, peneliti juga berharap guru dapat melakukan penelitian lebih lanjut tentang penggunaan strategi pembelajaran berbasis masalah pada mata pelajaran maupun tingkat kelas yang berbeda sehingga diperoleh hasil yang lebih menyeluruh dan dapat dijadikan sebagai penyeimbang teori maupun reformasi bagi dunia pendidikankhususnya pada aspek peningkatan hasil belajar siswa.

\section{DAFTAR PUSTAKA}

Djamarah, S.B., dan Zain, A. (2010). Strategi Belajar Mengajar. Jakarta: Rineka Cipta.

Hamalik, O. (2010). Proses Belajar Mengajar, Jakarta: Bumi Aksara.

Jauhar, M. (2011). Implementasi PAIKEM dari Behavioristik Sampai Konstuktivistik: Sebuah Pengembangan Pembelajaran Berbasis CTL (Contextual Teaching \& Learning), Jakarta: Prestasi Pustakaraya.

Riyanto, Y. (2010). Paradigma Baru Pembelajaran sebagai Referensi bagi Guru dalam Implementasi Pembelajaran yang Efektif danBerkualitas. Jakarta: Kencana

Rusman. (2010). Model-Model Pembelajaran: Mengembangkan Profesionalisme Guru. Jakarta: Raja Grafindo Persada.

Sagala, S. (2009). Konsep dan Makna Pembelajaran, Untuk Membantu Memecahkan Problematika Belajar dan Mengajar, Bandung: Alfabeta.

Sanjaya, W. (2010). Penelitian Tindakan Kelas, Jakarta: Kencana.

Slameto. (2010). Belajar dan Faktor-faktor yang Mempengaruhinya, Jakarta: Rineka Cipta. 
Sudjana, N. (2009). Penilain Hasil Proses Belajar Mengajar, Bandung: Remaja Rosdakarya Syah, M. (2010). Psikologi Belajar. Jakarta: Raja Grafindo Persada. 